\title{
Angka Mortalitas pasien Neonatus yang Menjalani Operasi berdasar atas Kenaikan Berat Badan Pascaoperasi yang Dirawat di Neonatal Intensive Care Unit (NICU) RSUP Dr. Hasan Sadikin Bandung
}

\author{
Asep Deden Komara, Budiana Rismawan, Ezra Oktaliansah \\ Departemen Anestesiologi dan Terapi Intensif \\ Fakultas Kedokteran Universitas Padjadjaran/RSUP Dr. Hasan Sadikin Bandung
}

\begin{abstract}
Abstrak
Salah satu faktor risiko mortalitas pada neonatus yang menjalani operasi adalah regulasi cairan intraoperatif. Tujuan penelitian ini mengetahui angka mortalitas pada neonatus yang menjalani operasi berdasar atas kenaikan berat badan pascaoperasi yang dirawat di Neonatal Intensive Care Unit (NICU). Metode penelitian adalah deskriptif dengan pendekatan retrospektif. Penelitian ini melibatkan 95 subjek penelitian, yaitu neonatus yang menjalani operasi dan dirawat di NICU RSHS selama tahun 2010-2015. Data diambil dari rekam medis, pengambilan data mulai tanggal 1 Februari sampai dengan 29 Maret 2017. Subjek dibagi tiga kelompok, yaitu neonatus yang telah menjalani prosedur operasi yang mengalami kenaikan berat badan pascaoperasi kurang $10 \%$ (I), neonatus yang menjalani prosedur operasi yang mengalami kenaikan berat badan $10-20 \%$ (II), dan kelebihan berat badan $\geq 20 \%$ (III). Neonatus pacaoperasi dengan kenaikan berat badan $\leq 10 \%$ sebanyak 46 pasien dan yang meninggal sebanyak 10 pasien pada kenaikan berat badan $10-20 \%$ sebanyak 38 pasien, pasien yang meninggal sebanyak 23 pasien, angka mortalitasnya sebesar $60,5 \%$, sedangkan pada pasien dengan kenaikan berat badan sama dengan atau lebih dari $20 \%$ sebanyak 11 pasien atau $11,5 \%$ yang meninggal sebanyak 10 pasien, angka mortalitasnya sebesar $90,9 \%$. Simpulan angka mortalitas pasien neonatus yang menjalani operasi di RSHS dan pascaoperasi dirawat di NICU RSHS selama periode $2010-2015$ adalah $45,3 \%$. Simpulan, angka mortalitas pasien neonatus yang menjalani operasi di RSHS dan pascaoperasi dirawat di NICU RSHS selama periode 2010-2015 adalah 45,3\%.
\end{abstract}

Kata kunci: Kenaikan berat badan, mortalitas, neonatus

\section{Mortality Rate in Neonatal Patients Undergone Surgical Procedures based on Postoperative Weight Gain in Neonatal Intensive Care Unit of Dr. Hasan Sadikin General Hospital Bandung}

\begin{abstract}
One of the risk factors contributed to this number is the inappropriate management of intraoperative fluid resuscitation. The aim of this study was to identify the mortality rate of neonatal patients who had undergone surgical procedures-defined by postoperative weight gain of those patients admitted in the Neonatal Intensive Care Unit (NICU). This study was retrospective descriptive study involving 95 subjects, who were neonatal patients undergone surgical procedures and admitted in Neonatal Intensive Care Unit (NICU) of Dr. Hasan Sadikin General Hospital (RSHS) Bandung from 2010-2015. The data were collected from medical records using a protocol that was already approved by the Ethical Committee during the period of February 1st to March 29th 2017. The subjects were classified into three groups: neonatal patients with increased postoperative weight of less than 10\%; neonatal patients which increased postoperative weight of $10-20 \%$; and neonatal patients with increased postoperative weight of $\geq 20 \%$. Results of the study showed that 46 neonatal patients experienced a $10 \%$ weight gain (48\%) and 10 out of these 46 patients died (21.7\%). Meanwhile, 38 neonatal patients experienced 10-20\% (38.9\%) weight gain with 23 of them died $(60.5 \%)$. Eleven neonatal patients experienced $\geq 20 \%$ weight gain $(11.5 \%)$ with 10 of them died $(90.9 \%)$. In conclusion, it is concluded that the mortality rate of postoperative neonatal patients treated in NICU of RSHS during the period 2010 to 2015 is $45.3 \%$.
\end{abstract}

Key words: Weight gain, mortality, neonatal

Korespondensi: Asep Deden Komara, dr., SpAn, Departemen Anestesiologi dan Terapi Intensif Fakultas Kedokteran Universitas Padjadjaran/RSUP Dr. Hasan Sadikin Bandung, Jl. Pasteur No. 38 Bandung 40161, Tlpn. 022-2038285 Email asepdeko@gmail.com 


\section{Pendahuluan}

Pasien pediatrik mempunyai kebutuhan dan pertimbangan anestesi khusus serta tidak dapat dianggap seperti pasien dewasa yang berukuran kecil. Penatalaksanaan anestesi yang aman pada pediatrik bergantung pada penilaian keseluruhan karakteristik fisiologi, anatomi, dan farmakologi pada tiap-tiap kelompok. Salah satu kelompok pasien pediatrik adalah pasien neonatus yang memiliki kebutuhan obat-obat anestesi yang berbeda dibanding dengan pasien pediatrik pada umumnya. Neonatus memiliki risiko morbiditas dan mortalitas tertinggi pada

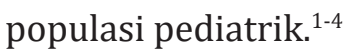

Risiko mortalitas yang tinggi pada kelompok neonatus merupakan tantangan bagi dokter anestesi dan membutuhkan kerjasama tim yang melibatkan dokter ahli bedah anak, dokter ahli kesehatan anak, serta orangtua pasien. Faktor risiko yang ditemukan pada golongan neonatus antara lain prematuritas, berat badan lahir rendah, infeksi, kelainan kromosom, dan kelainan genetik yang membutuhkan penanganan khusus di Neonatus Intensive Care Unit (NICU). ${ }^{3,5,6}$

Perkembangan yang pesat di bidang keilmuan kesehatan anak, bedah anak, dan anestesi, serta unit perawatan khusus untuk neonatus yang disertai dengan alat-alat yang modern akan meningkatkan angka keberhasilan hidup pada operasi neonatus di negara maju dan negara berkembang. ${ }^{3,7-9}$

Salah satu faktor risiko mortalitas yang belum banyak diteliti pada kelompok usia neonatus yang menjalani pembedahan adalah regulasi pemberian cairan intraoperatif. Kebutuhan cairan pada neonatus harus dihitung dengan hati-hati dan tepat serta dievaluasi ulang pada saat intraoperatif oleh dokter anestesi. Selama lebih dari 40 tahun terakhir, pola pemberian cairan pada neonatus dan anak tidak banyak berubah, ahli anestesi di Amerika, Eropa, dan Asia masih menggunakan metode pemberian cairan dengan formula Holliday-Segar yang pertama kali digunakan pada tahun $1957.6,8,9$
Pemberian cairan perioperatif harus menjadi perhatian dokter anestesi karena dapat memengaruhi hasil luaran pascaoperasi. Saat ini masih terdapat perbedaan pendapat dalam hal metode pemberian cairan perioperatif, yakni melalui metode liberal dan restriktif. Banyak dampak yang disebabkan oleh kelebihan pemberian cairan selama perioperatif dapat dilihat dari kenaikan berat badan (BB) pascaoperasi dibanding dengan berat badan sebelum operasi yang dapat mengakibatkan komplikasi berbagai organ, lama penggunaan ventilator, dan lama perawatan di rumah sakit. Oleh karena itu, evaluasi keseimbangan pemberian cairan selama perioperatif sangat diperlukan untuk mencegah berbagai komplikasi tersebut yang akan mengakibatkan morbiditas dan mortalitas pascaoperasi pada pasien neonatus yang menjalani operasi. ${ }^{5,11,12}$

Penelitian tentang pemberian cairan selama perioperatif menunjukkan bahwa pemberian cairan secara restriktif memberikan hasil luaran yang lebih baik. Hal ini dapat dilihat dari komplikasi pascaoperasi berkurang dan juga lama perawatan di ruang intensif yang akan menurunkan angka morbiditas dan mortalitas. Pemberian cairan secara liberal berdasar atas penelitian menunjukkan bahwa hasil luaran pascaoperasi berupa kelebihan cairan yang ditandai dengan kenaikan berat badan pascaoperasi, komplikasi pascaoperasi, lama perawatan, dan penggunaan ventilator $\mathrm{di}$ ruang intensif. ${ }^{7,13-15}$

Penelitian angka kejadian mortalitas pada pasien neonatus yang menjalani operasi berdasar atas kenaikan berat badan pascaoperasi yang dirawat di Neonatus Intensif Care Unit (NICU) RSUP Dr. Hasan Sadikin Bandung selama ini belum pernah dilakukan sehingga belum didapatkan angka kejadian mortalitas pada pasien neonatus yang menjalani operasi berdasar atas kenaikan berat badan pascaoperasi yang dirawat di NICU RSUP Dr. Hasan Sadikin Bandung.

Penelitian ini bertujuan mengetahui angka mortalitas pasien neonatus yang menjalani operasi berdasar atas kenaikan berat badan pascaoperasi yang dirawat di NICU RSUP 
Dr. Hasan Sadikin Bandung selama tahun 2010-2015.

\section{Subjek dan Metode}

Penelitian ini merupakan penelitian deskriptif dengan pendekatan retrospektif. Pengambilan data penelitian secara keseluruhan dilakukan dalam kurun waktu dua bulan, yaitu bulan Februari sampai dengan bulan Maret 2017, data diambil dari rekam medis setelah mendapat persetujuan dari Komite Etik Penelitian Kesehatan Fakultas Kedokteran Universitas Padjadjaran/Rumah Sakit Umum Pusat Dr. Hasan Sadikin Bandung. Kriteria inklusi penelitian ini adalah pasien neonatus yang telah menjalani operasi di RSUP Dr. Hasan Sadikin dan pascaoperasi dirawat di ruang NICU RSUP Dr. Hasan Sadikin Bandung dari tahun 2010-2015. Kriteria eksklusi penelitian ini adalah tidak ada data berat badan sebelum dan sesudah operasi.

Data yang dicatat, yaitu nama, rekam medis, jenis kelamin, usia saat operasi, usia gestasi, berat badan sebelum operasi, berat badan sesudah operasi, jenis operasi elektif atau emergensi, komplikasi preoperatif, lama operasi, komplikasi pascaoperasi, lama perawatan, dan hasil luaran. Kemudian, seluruh neonatus dikelompokkan berdasar atas persentase kenaikan berat badan menjadi tiga kelompok, yaitu kelompok I adalah neonatus yang telah menjalani prosedur operasi dengan kenaikan berat badan pascaoperasi kurang dari 10\%; kelompok II adalah neonatus yang menjalani prosedur operasi dengan kenaikan berat badan antara 10 sampai kurang dari $20 \%$; kelompok III kelebihan berat badan lebih atau sama dengan $20 \%$. Selanjutnya, dinilai angka mortalitas berdasar atas persentase kenaikan berat badan pascaoperasi. Data yang diperoleh dicatat dalam formulir khusus, kemudian diolah melalui program statistical product and service solution (SPSS) versi 21.0 for windows.

\section{Hasil}

Penelitian restrospektif ini dilakukan terhadap 95 neonatus yang telah menjalani operasi
Tabel 1 Karakteristik Subjek Penelitian

\begin{tabular}{|c|c|}
\hline Variabel & $n=95$ \\
\hline \multicolumn{2}{|l|}{ Usia (hari) } \\
\hline Mean \pm STD & $8,915 \pm 7,1587$ \\
\hline Median & 6.000 \\
\hline Range (min.-max.) & 0,$00 ; 28,00$ \\
\hline \multicolumn{2}{|l|}{ Jenis kelamin } \\
\hline Laki-laki & $51(54 \%)$ \\
\hline Perempuan & $44(46 \%)$ \\
\hline \multicolumn{2}{|l|}{ Usia gestasi (minggu) } \\
\hline$<37$ & $32(34 \%)$ \\
\hline$\geq 37$ & $63(66 \%)$ \\
\hline \multicolumn{2}{|l|}{ BB preoperatif (gram) } \\
\hline$<2.500$ & $40(42 \%)$ \\
\hline$\geq 2.500$ & $55(58 \%)$ \\
\hline \multicolumn{2}{|l|}{ Jenis operasi } \\
\hline Elektif & $47(49 \%)$ \\
\hline Emergensi & $48(51 \%)$ \\
\hline \multicolumn{2}{|l|}{ Macam operasi } \\
\hline Digestif & $57(60 \%)$ \\
\hline Nondigestif & $38(40 \%)$ \\
\hline $\begin{array}{r}\text { ASA } \\
\text { III } \\
\text { IV }\end{array}$ & $\begin{array}{l}60(63 \%) \\
35(37 \%)\end{array}$ \\
\hline $\begin{array}{l}\text { Komplikasi preopera } \\
\text { Tidak ada } \\
1 \text { komplikasi } \\
2 \text { komplikasi } \\
3 \text { komplikasi }\end{array}$ & $\begin{array}{c}56(59 \%) \\
27(28 \%) \\
11(12 \%) \\
1(1 \%)\end{array}$ \\
\hline \multicolumn{2}{|c|}{ Persentase kenaikan BB pascaoperai } \\
\hline$<10 \%$ & $46(48 \%)$ \\
\hline $10-20 \%$ & $38(40 \%)$ \\
\hline$>20 \%$ & $11(12 \%)$ \\
\hline \multicolumn{2}{|l|}{ Hasil luaran } \\
\hline Hidup & $52(55 \%)$ \\
\hline Meninggal & $43(45 \%)$ \\
\hline
\end{tabular}

di RSUP Dr. Hasan Sadikin (RSHS) Bandung dan dirawat di NICU RSHS Bandung. Usia rata-rata pasien (hari) 8,915 \pm 7.1587 . Jenis kelamin laki-laki lebih banyak daripada perempuan (54\%). Pasien neonatus yang menjalani operasi pada usia usia gestasi lebih 
Tabel 2 Mortalitas berdasar atas Kenaikan Berat Badan

\begin{tabular}{lcccc}
\hline \multirow{2}{*}{ Mortalitas } & \multicolumn{3}{c}{ Kelompok } & \multirow{2}{*}{$\mathbf{n = 9 5}$} \\
\cline { 2 - 4 } & $\begin{array}{c}\mathbf{1} \mathbf{1 0 \%} \\
\mathbf{n = 4 6}\end{array}$ & $\begin{array}{c}\mathbf{1 0 - 2 0 \%} \\
\mathbf{n = 3 8}\end{array}$ & $\begin{array}{c}\mathbf{2 0 \%} \\
\mathbf{n = 1 1}\end{array}$ & \\
\hline Hidup & $36(78 \%)$ & $15(39 \%)$ & $1(9 \%)$ & 52 \\
Mati & $10(22 \%)$ & $23(61 \%)$ & $10(91 \%)$ & 43 \\
\hline
\end{tabular}

dari 37 minggu lebih banyak daripada usia gestasi kurang dari 37 minggu (66\%). Pasien neonatus yang menjalani operasi dengan berat badan preoperatif lebih dari 2.500 gram lebih banyak daripada berat badan preoperatif kurang dari 2.500 gram, yaitu 58\% (Tabel 1).

Pasien neonatus yang menjalani operasi emergensi dan elektif tidak begitu banyak perbedaannya, pasien emergensi sebesar 51\%, dan pasien neonatus yang menjalani operasi digestif ditemukan lebih banyak daripada operasi nondigestif, yaitu sebesar 59\%. Pasien neonatus yang menjalani operasi ASA III lebih banyak daripada ASA IV, yaitu 63\%. Pasien neonatus yang menjalani operasi yang tidak ditemukan komplikasi preoperatif lebih banyak daripada yang terdapat komplikasi preoperatif, yaitu 59\%. Pasien neonatus yang menjalani operasi dengan persentase kenaikan berat badan pascaoperasi kurang dari 10\% lebih banyak daripada kenaikan lebih dari $10 \%$, yaitu $48 \%$, pasien neonatus pascaoperasi yang dirawat di NICU RSHS yang hidup ditemukan lebih banyak daripada yang meninggal, yaitu 55\% (Tabel 1).

Angka mortalitas tertinggi didapatkan pada kenaikan berat badan neonatus pascaoperasi lebih dari 20\%, yaitu 10 dari 11, kenaikan berat badan neonatus pascaoperasi $10-20 \%$ didapatkan angka mortalitas 23 dari 38 subjek, kenaikan berat badan neonatus pascaoperasi kurang dari 10\% angka mortalitas 10 dari 46

Tabel 3 Mortalitas Persentase Kenaikan Berat Badan berdasar atas Usia Gestasi, Berat Badan Sebelum Operasi, dan ASA

\begin{tabular}{|c|c|c|c|c|}
\hline \multirow{2}{*}{ Variabel } & \multicolumn{3}{|c|}{ Kelompok } & \multirow{2}{*}{$\mathbf{n}$} \\
\hline & $<10 \%$ & $10-20 \%$ & $>20 \%$ & \\
\hline \multicolumn{5}{|l|}{$<37$ minggu } \\
\hline $\begin{array}{l}\text { Hidup } \\
\text { Meninggal } \\
\geq 37 \text { minggu }\end{array}$ & $\begin{array}{l}1 \\
6\end{array}$ & $\begin{array}{c}5 \\
11\end{array}$ & $\begin{array}{l}1 \\
8\end{array}$ & $\begin{array}{c}7 \\
25\end{array}$ \\
\hline $\begin{array}{l}\text { Hidup } \\
\text { Meninggal }\end{array}$ & $\begin{array}{c}35 \\
4\end{array}$ & $\begin{array}{l}10 \\
12\end{array}$ & $\begin{array}{l}0 \\
2\end{array}$ & $\begin{array}{l}45 \\
18\end{array}$ \\
\hline \multicolumn{5}{|l|}{$\mathrm{BB}<2.500$ gram } \\
\hline $\begin{array}{l}\text { Hidup } \\
\text { Meninggal } \\
\text { BB } \geq 2500 \text { gram }\end{array}$ & $\begin{array}{l}4 \\
7\end{array}$ & $\begin{array}{c}6 \\
14\end{array}$ & $\begin{array}{l}1 \\
8\end{array}$ & $\begin{array}{l}11 \\
29\end{array}$ \\
\hline $\begin{array}{l}\text { Hidup } \\
\text { Meninggal }\end{array}$ & $\begin{array}{c}32 \\
3\end{array}$ & $\begin{array}{l}9 \\
9\end{array}$ & $\begin{array}{l}0 \\
2\end{array}$ & $\begin{array}{l}41 \\
14\end{array}$ \\
\hline \multicolumn{5}{|l|}{ ASA III } \\
\hline $\begin{array}{l}\text { Hidup } \\
\text { Meninggal } \\
\text { ASA IV }\end{array}$ & $\begin{array}{c}34 \\
4\end{array}$ & $\begin{array}{c}14 \\
5\end{array}$ & $\begin{array}{c}1 \\
2(\end{array}$ & $\begin{array}{l}49 \\
11\end{array}$ \\
\hline $\begin{array}{l}\text { Hidup } \\
\text { Meninggal }\end{array}$ & $\begin{array}{l}2 \\
6\end{array}$ & $\begin{array}{c}1 \\
18\end{array}$ & $\begin{array}{l}0 \\
8\end{array}$ & $\begin{array}{c}3 \\
32\end{array}$ \\
\hline
\end{tabular}


Tabel 4 Mortalitas berdasar atas Komplikasi Preoperatif

\begin{tabular}{lcccc}
\hline \multirow{2}{*}{ Komplikasi Preoperatif } & \multicolumn{3}{c}{ Kelompok } & n \\
\cline { 2 - 4 } & $<\mathbf{1 0 \%}$ & $\mathbf{1 0 - 2 0 \%}$ & $\mathbf{2 0 \%}$ & \\
\hline Tidak ada & 26 & 11 & 1 & 38 \\
$\quad$ Hidup & 6 & 8 & 4 & 18 \\
$\quad$ Meninggal & & & & \\
1 Komplikasi & 10 & 3 & 0 & 13 \\
$\quad$ Hidup & 3 & 6 & 5 & \\
$\quad$ Meninggal & & & & 1 \\
2 Komplikasi & 0 & 1 & 0 & 10 \\
Hidup & 1 & 8 & 1 & 0 \\
$\quad$ Meninggal & 0 & 0 & 0 & 1 \\
3 Komplikasi & 0 & 1 & 0 & \\
$\quad$ Hidup & & & & \\
Meninggal & & &
\end{tabular}

subjek (Tabel 2).

Pada usia gestasi kurang dari 37 minggu/ prematur dengan post conceptional age (PCA) kurang dari 60 minggu, berat badan sebelum operasi kurang dari 2.500 gram, ASA III dan ASA IV didapatkan angka mortlitas tertinggi pada kelompok kenaikan berat badan lebih dari 20\% (Tabel 3).

Angka mortalitas berdasar atas komplikasi preoperatif, pada $\leq 2$ komplikasi preoperatif didapatkan angka mortalitas tertinggi pada kelompok kenaikan berat badan lebih dari $20 \%$. Pasien neonatus yang menjalani operasi dengan 3 komplikasi preoperatif terdapat satu pasien dan meninggal terdapat pada kelompok kenaikan berat badan 10-20\% (Tabel 4).

Angka mortalitas berdasar atas lama operasi, pada operasi lebih dari 2 jam angka mortalitas tertinggi didapatkan padakelompok kenaikan berat badan lebih dari 20\%. Pada operasi kurang dari 2 jam angka mortalitas tertinggi didapatkan pada kelompok kenaikan berat badan $10-20 \%$, pada lama operasi kurang dari 2 jam tidak didapatkan kenaikan berat badan lebih dari 20\% (Tabel 5).

Lama perawatan di NICU Dr. RSHS Bandung, paling lama didapatkan pada kelompok dengan kenaikan berat badan lebih dari 20\% rata-rata 31,090 $\pm 45,502$ (Tabel 6).

\section{Pembahasan}

Operasi pada pasien neonatus saat ini masih memiliki angka mortalitas yang lebih tinggi

Tabel 5 Mortalitas berdasar atas Lama Operasi

\begin{tabular}{lccc}
\hline & Variabel & & Kelompok \\
\cline { 2 - 4 } & $<\mathbf{1 0 \%}$ & $\mathbf{1 0 - 2 0 \%}$ & $\mathbf{2 0 \%}$ \\
\hline$\leq 2$ jam & 1 & 1 & 0 \\
Mati & 9 & 2 & 0 \\
Hidup & & & \\
$>2-4$ jam & 7 & 17 & 9 \\
Mati & 25 & 13 & 1 \\
Hidup & & & 1 \\
$>4$ jam & 2 & 5 & 0 \\
Mati & 1 & 1 & \\
Hidup & &
\end{tabular}


Tabel 6 Lama Perawataan pada Tiga Kelompok Persentase

\begin{tabular}{|c|c|c|c|}
\hline \multirow[b]{2}{*}{ Variabel } & \multicolumn{3}{|c|}{ Kelompok } \\
\hline & $\begin{array}{l}<10 \% \\
n=46\end{array}$ & $\begin{array}{c}10-20 \% \\
n=38\end{array}$ & $\begin{array}{l}>20 \% \\
n=11\end{array}$ \\
\hline Mean \pm STD & $21,543 \pm 13,593$ & $26,868 \pm 22,025$ & $31, .090 \pm 45,502$ \\
\hline Median & 22.000 & 22.000 & 21.000 \\
\hline Range (min.-maks.) & $0,00-62,00$ & $1, .00-102, .00$ & $0,00-161,00$ \\
\hline
\end{tabular}

dibanding dengan pasien bayi, anak, dan dewasa terutama di negara berkembang termasuk Indonesia. Operasi neonatus merupakan tantangan bagi dokter anestesi, dokter anak, dan dokter bedah anak, terutama di negara berkembang seperti Indonesia karena praktik bedah pada neonatus yang masih terus berkembang. ${ }^{12,13}$

Penelitian ini dilakukan terhadap 95 neonatus yang menjalani operasi di RSUP Dr. Hasan Sadikin Bandung dan pascaoperasi dirawat di ruang perawatan NICU RSUP Dr. Hasan Sadikin Bandung sesuai kriteria inklusi. Dari hasil penelitian didapatkan angka mortalitas neonatus pascaoperasi sebanyak 43 pasien (45\%). Keadaan ini menggambarkan angka mortalitas pascaoperasi yang tinggi pada neonatus. Angka mortalitas pascaoperasi yang tinggi pada pasien neonatus ini menggambarkan bahwa usia merupakan salah satu faktor yang memengaruhi hasil luaran pasien. Semakin muda usia pasien neonatus, akan semakin besar risiko mortalitas pascaoperasi. Pada neonatus fungsi organ tubuh seperti jantung, paru, ginjal, dan hepar belum berfungsi seperti halnya pasien dewasa. Selain itu, neonatus juga sangat rentan terhadap infeksi. ${ }^{9}, 10,16$

Penelitian yang dilakukan di India antara tahun 1996 sampai 2006 terhadap neonatus yang menjalani operasi dan pascaoperasi yang dirawat di ruang intensif neonatus didapatkan angka mortalitas mencapai 40\%. ${ }^{11}$ Keadaan ini sesuai dengan penelitian yang dilakukan selama tiga tahun di Nigeria untuk pasien neonatus yang menjalani operasi, angka mortalitas pascaoperasi mencapai $62,2 \%$. Penelitian di Kenya pada neonatus yang menjalani operasi angka mortalitas pascaoperasi mencapai $44 \%$, sedangkan di Kamerun angka mortalitas pascaoperasi mencapai $43,1 \%{ }^{9}$

Pada penelitian ini angka mortalitas tertinggi terdapat pada kelompok neonatus yang mengalami kenaikan berat badan pascaoperasi lebih dari $20 \%$ adalah 10 dari 11 , kenaikan berat badan pascaoperasi $10-20 \%$ didapatkan mortalitas 23 dari 38 subjek. kenaikan berat badan pascaoperasi kurang dari 10\% mortalitas adalah 10 dari 46 (Tabel 2). Angka kejadian mortalitas pascaoperasi pada neonatus saat ini masih tinggi. Beberapa faktor yang memengaruhi hasil luaran operasi, yaitu usia neonatus yang prematur, usia gestasi kurang dari 37 minggu, banyaknya komplikasi preoperatif, ASA III atau lebih, lama operasi, perawatan pascaoperasi, kemudian pengaruh kenaikan berat badan juga memberikan dampak terhadap hasil luaran operasi yang akan meningkatkan angka mortalitas pascaoperasi. Hal ini disebabkan oleh fungsi organ neonatus masih belum berkembang seperti pada orang dewasa sehingga sangat rentan tehadap infeksi terutama infeksi pascaoperasi. Akibat kelebihan cairan ini akan memengaruhi hasil luaran operasi yang akan mengganggu sistem organ tubuh neonatus dan akan memperberat kondisi neonatus tersebut. Angka mortalitas yang tinggi pada pasien neonatus juga dapat disebabkan oleh keterlambatan pasien neonatus datang ke tempat pelayanan kesehatan atau rumah sakit, keterlambatan diagnosis yang tepat, dan keterlambatan dalam pengambilan keputusan untuk dilakukan tindakan operasi. Pengaruh katerlambatan penanganan pasien neonatus ini akan mengakibatkan kondisinya semakin memburuk dan dapat 
memengaruhi hasil luaran jika dilakukan tindakan operasi, keadaan seperti ini banyak ditemukan di negara berkembang termasuk di Indonesia. ${ }^{9,11,17}$

Pada penelitian ini didapatkan angka mortalitas pascaoperasi pada neonatus meningkat sebanyak 2,7 kali lebih tinggi atau hampir tiga kali apabila terjadi kenaikan berat badan pascaoperasi $10-20 \%$ dibanding dengan kenaikan berat badan kurang dari $10 \%$. Selanjutnya, angka mortalitas akan meningkat menjadi 4,1 kali lebih tinggi atau empat kali lebih tinggi jika terjadi kenaikan berat badan lebih dari $20 \%$ pascaoperasi dibanding dengan kenaikan berat badan kurang dari $10 \%$. Hal ini menunjukkan bahwa makin tinggi kenaikan berat badan pascaoperasi memiliki hasil luaran pascaoperasi yang sangat buruk terhadap kondisi pasien yang mengakibatkan angka mortalitas pascaoperasi yang tinggi. ${ }^{3,5,15}$

Keadaan ini sesuai dengan penelitian yang dilakukan di Amerika Serikat terhadap pasien pascaoperasi yang dirawat di Intensive Care Unit (ICU) bahwa $40 \%$ pasien mengalami kelebihan berat badan lebih dari 10\% dibanding dengan berat badan preoperatif. Hal ini menandakan terjadi kelebihan pemberian cairan selama perioperatif yang secara signifikan meningkatkan angka morbiditas dan mortalitas, serta lama perawatan di ICU. Pascaoperasi pasien dengan kenaikan berat badan lebih dari 10\% angka mortalitas mencapai $31,6 \%$, sedangkan pasien dengan kenaikan berat badan kurang dari 10\% angka mortalitas 10,3\% dan pasien dengan kenaikan berat badan lebih dari 20\% angka kejadian mortalitas mencapai $100 \% .{ }^{5}$ Penelitian yang dilakukan di Afrika Selatan pada tahun 2014 menunjukkan hubungan kelebihan pemberian cairan pada pasien yang dirawat di ruang Pediatric Intensive Care Unit(PICU).Pada pasien yang kelebihan cairan kurang dari 10\% angka mortalitas sebesar 8,2\%, sedangkan pada pasien yang kelebihan cairan lebih dari $10 \%$ angka mortalitas sebesar $66,7 \% .{ }^{4}$ Penelitian yang dilakukan di Brazil menunjukkan bahwa kelebihan cairan positif 5\% sampai 10\% dari pertambahan berat badan pada pasien sakit kritis mempunyai prognosis yang lebih buruk dengan berbagai gangguan fungsi organ pada pasien yang menjalani operasi. ${ }^{2,17}$

Angka mortalitas pada usia gestasi kurang dari 37 minggu berdasar atas kenaikan berat badan pascaoperasi didapatkan 32 pasien dengan angka mortalitas 78\% (Tabel 3). Pasien neonatus yang lahir disebut prematur jika usia gestasi kurang dari 37 minggu, bayi prematur memiliki angka mortalitas pascaoperasi yang lebih tinggi dibanding dengan bayi lahir cukup bulan. Pasien neonatus yang prematur dan post conceptional age (PCA) kurang dari 60 minggu memiliki risiko komplikasi pascaoperasi yang lebih tinggi seperti kejadian periode sleep apneu yang lebih tinggi, lebih mudah untuk terjadi hipotermia, risiko terjadi retinopati, risiko terjadi infeksi yang lebih tinggi, pasien prematur memiliki sistem kekebalan tubuh yang masih lemah dan belum matang dapat meningkatkan risiko infeksi.

Pasien lahir prematur yang menjalani operasi memiliki angka mortalitas yang tinggi, pada penelitian ini didapatkan bahwa kenaikan berat badan pascaoperasi, jika dilihat angka mortalitasnya tidak begitu berpengaruh yang berkisar 78,1-89\%. Keadaan ini terjadi karena kondisi pasien neonatus yang prematur sebelum dilakukan tindakan operasi sudah memiliki banyak penyulit seperti berat badan kurang dari 2.500 gram, ASA III atau lebih, kelainan kongenital yang lain seperti penyakit jantung bawaan dan komplikasi preoperatif lain. Keadaan umum yang buruk seperti ini banyak kita jumpai pada pasien neonatus lahir prematur sehingga jika dilakukan operasi akan mengakibatkan angka mortalitas pascaoperasi yang tinggi ditambah dengan kenaikan berat badan pascaoperasi akan lebih meningkatkan angka mortalitas. ${ }^{2,12}$

Pasien neonatus yang menjalani operasi yang memiliki berat badan kurang dari 2.500 gram (Tabel 3) memiliki risiko mortalitas yang lebih tinggi bila dibanding dengan neonatus yang berat badan lebih 2.500 gram karena neonatus dengan berat badan yang kurang dari 2.500 gram sebagian besar lahir prematur, terdapat kelainan bawaan yang lain. Pasien prematur memiliki risiko infeksi, hipotermia, hipoglikemia, dan priode sleep apnea yang 
Asep Deden Komara, Ezra Oktaliansah, Budiana Rismawan: Angka Mortalitas pasien Neonatus yang Menjalani Operasi

lebih tinggi yang akan meningkatkan kejadian morbiditas dan mortalitas. ${ }^{2,13}$

Angka mortalitas lebih tinggi juga didapatkan pada bayi prematur dan bayi dengan berat badan kurang dari 2.500 gram. Hal ini sesuai dengan penelitian di Amerika Serikat yang menunjukkan bahwa pasien prematur memiliki angka mortalitas yang lebih tinggi dibanding dengan pasien lahir cukup bulan yang menjalanani operasidengan angka mortalitas pascaoperasi mencapai $10,5 \%$ dibanding dengan pasien cukup bulan angka mortalitas pascaoperasi hanya $2 \%$. Penelitian yang dilakukan di Nigeria terhadap pasien neonatus yang menjalani operasi selama 10 tahun dari tahun 1993 sampai tahun 2002, didapatkan bahwa berat badan sebelum operasi secara signifikan berperan besar terhadap hasil luaran pascaoperasi semua pasien yang berat badan kurang dari 2.000 gram pascaoperasi meninggal karena pasien dengan berat badan lebih dari 3.000 gram didapatkan angka mortalitas sebesar $16,7 \%{ }^{20}$ Dari penelitian ini didapatkan angka mortalitas pada pasien prematur dan berat badan kurang dari 2.500 gram lebih tinggi disebabkan oleh banyak fungsi organ yang belum berkembang dengan sempurna dan risiko infeksi lebih tinggi. ${ }^{13}$

Pada penelitian ini dapat dilihat bahwa angka mortalitas pascaoperasi pada pasien neonatus berdasar atas ASA (Tabel 3), yaitu pasien ASA IV memiliki angka mortalitas lebih tinggi dibanding dengan pasien ASA III dan dengan kenaikan berat badan pascaoperasi akan meningkatkan lagi angka mortalitas pascaoperasi. Pasien dengan ASA III atau lebih memiliki keadaan umum yang jelek dan lebih banyak penyulit mulai dari preoperatif seperti lahir prematur, berat badan kurang dari 2.500 gram, dan kelainan kongenital yang lain, serta keterlambatan penanganan pasien untuk dilakukan tindakan operasi yang akan memperburuk kondisi pasien. Penelitian yang dilakukan di Prancis pada tahun 2006 memperlihakan bahwa pasien dengan ASA IV yang dilakukan tindakan anestesi memiliki angka mortalitas yang lebih tinggi dibanding dengan ASA III. Pasien dengan ASA IV angka mortalitasnya 55 per 100.000 prosedur anestesi, sedangkan pasien dengan ASA III angka mortalitasnya 27 per 100.000 prosedur anestesi, dari angka tersebut dapat dilihat angka mortalitas pada pasien ASA IV lebih dua kali lebih tinggi dibanding dengan pasien ASA III. $^{7}$

Berdasar atas penelitian ini didapatkan angka mortalitas tertinggi pada pasien yang memiliki 3 komplikasi preoperatif satu neonatus dan meninggal (Tabel 4). Komplikasi preoperatif berhubungan dengan keadaan umum pasien sebelum dilakukan tindakan bedah dan anestesi, keadaan ini menandakan keadaan umum yang jelek, semakin banyak komplikasi preoperatif akan semakin jelek keadaan umum pasien. Hal ini sangat berhubungan dengan ASA pasien yang tinggi sehingga angka mortalitas lebih tinggi. Pasien neonatus yang akan dioperasi bertujuan memperbaiki kelainan bawaan. Komplikasi preoperatif pada neonatus ini saling berhungan dengan beberapa faktor antara lain bayi lahir prematur, berat badan lahir rendah, keterlambatan datang ke fasilitas kesehatan atau rumah sakit, keterlambatan menegakkan diagnosis, keterlambatan keputusan dilakukan tindakan operasi, dan pasien neonatus/ prematur memiliki ASA yang tinggi memiliki angka mortalitas yang lebih tinggi..$^{9,15}$

Teknik pemberian cairan hingga saat ini masih menjadi perdebatan antara para ahli, salah satu teknik yang masih sering digunakan, yaitu teknik pemberian cairan secara liberal. Untuk pemberian cairan secara liberal masih dapat dilakukan pada pasien ASA I-III dengan risiko rendah yang dilakukan operasi minor/ tindakan bedah yang minimal dan lama tindakan operasi kurang dari 180 menit, sedangkan pada pasien ASA I-IV dengan tidakan operasi yang besar memiliki risiko mortalitas yang tinggi, lama operasi yang lebih dari 180 menit, dan pemberian cairan secara restriktif memberikan hasil luaran yang lebih baik dibanding dengan cara yang liberal. ${ }^{15}$

Angka mortalitas pasien neonatus yang menjalani operasi bepengaruh terhadap lamanya operasi (Tabel 5). Angka mortalitas pada pasien yang menjalani operasi lebih dari 
4 jam 8 dari 10. Mortalitas tertinggi didapatkan pada kenaikan berat badan lebih dari 20\% (1 dari 1 subjek) kenaikan berat badan 10-20\% 5 dari 6 subjek dan kenaikan berat badan kurang dari 10\% adalah 2 dari 3 subjek. Lama operasi ini dapat menggambarkan jenis operasi yang dilakukan lebih rumit dan sulit untuk mengoreksi kelainan kongenital pada pasien neonatus, makin lama paparan/stres dari obatobatan anestesi, makin banyak manipulasi tindakan bedah yang akan mengakibatkan makin jelek kondisi pascaoperasi.

Lama operasi dan tindakan anestesi akan memengaruhi angka mortalitas pascaoperasi. Keadaan ini sesuai dengan penelitian di Inggris memperlihatkan angka mortalitas meningkat dengan lamanya operasi. Pada operasi kurang dari 2 jam angka mortalitasnya hanya 1,6 per 100 pasien, pada operasi 2-6 jam angka mortalitasnya 7,05 per 1.000 pasien dan yang menjalani operasi antara 6 sampai lebih dari 10 jam angka mortalitasnya 14,4 per 100 pasien. ${ }^{11}$

Perioperatif kelebihan pemberian cairan salah satu tanda dapat dilihat dari kenaikan berat badan pascaoperasi dibanding dengan berat badan sebelum operasi. Keadaan ini mengakibatkan hipervolemia sehingga lapisan endotelial vaskular mengalami kerusakan. Kerusakan ini menyebabkan pelepasan atrial natriuretic peptide (ANP) dan gangguan fungsi glycocalyx atau vascular endothelial junction sehingga cairan bergerak ke dalam ruang interstisial yang meningkatkan volume cairan interstisial sehingga terjadi edema interstitial yang merugikan. Hal ini berkaitan dengan angka morbiditas dan mortalitas yang meningkat, serta berdampak terhadap komplikasi pascaoperasi, lama perawatan di ruang rawat intensif. ${ }^{5,10,12}$ Kelebihan cairan dapat mengganggu pada beberapa organ seperti paru-paru. Resusitasi cairan yang berlebihan dapat mengakibatkan edema paru akut yang dapat menganggu pertukaran gas dan juga pasien lebih rentan terhadap risiko infeksi pada paru-paru sehingga membutuhkan alat bantuan napas ventilator pascaoperasi yang akan meningkatkan risiko pneumonia.
Pada saluran pencernaan juga dapat terjadi edema meningkatkan risiko ileus pascaoperasi dan terjadi gangguan waktu pengosongan lambung serta mengurangi drainase sistem limfatik dan oksigenasi yang akan mengakibatkan gangguan proses penyembuhan pada operasi anastomosis. Secara keseluruhan, jika terjadi kelebihan cairan pascaoperasi dapat mengakibatkan edema dalam jaringan dan interstitial yang mengganggu difusi oksigen dan metabolisme, gangguan di jaringan berupa obstruksi sistem aliran darah kapiler dan drainase sistem limfatik, serta gangguan interaksi antara sel. ${ }^{2,3}$ Pasien neonatus pascaoperasi lebih rentan terjadi sepsis yang sampai saat ini masih merupakan penyebab mortalitas pada neonatus. Meskipun angka kejadian sepsis lebih rendah di banyak pusat pelayanan kesehatan yang canggih, tetapi angka kejadian pascaoperasi seperti infeksi luka dan sepsis tetap ada dan masih menjadi penyebab mortalitas serta morbiditas yang akan meningkatkan lama perawatan. Sistem kekebalan tubuh pada neonatus yang masih lemah dan belum berkembang dengan baik dapat meningkatkan risiko sepsis. Hal ini merupakan tantangan tersendiri dalam penanganan pasien pada bayi baru lahir terutama pada bayi prematur. Keadaan ini diperberat oleh keadaan patologi yang mungkin memerlukan intervensi bedah dan dapat mengakibatkan neonatus sangat rentan terhadap infeksi pascaoperasi. Bayi yang lahir prematur dan berat badan rendah lebih rentan karena sistem kekebalan tubuh yang belum berkembang.

Neonatus yang menjalani operasi memiliki risiko yang lebih besar terjadi paparan bakteri patogen di lingkungan rumah sakit. Operasi pada saluran trakeo-esofagus, kelainan gastrointestinal, seperti obstruksi usus dengan berbagai etiologi, perforasi usus, necrosis enterocolitis (NEC), malformasi anorektal (MAR), defek pada dinding perut misalnya omfalokel atau gastroskisis yang paling rentan untuk terjadi sepsis. ${ }^{3,12,13}$ 


\section{Simpulan}

Angka mortalitas pasien neonatus yang menjalani operasi di RSHS dan pascaoperasi dirawat di NICU RSHS selama periode 20102015 adalah 45,3\%. Angka mortalitas berdasar atas kenaikan berat badan pascaoperasi $>20 \%$ paling tinggi. Faktor-faktor lain yang berpengaruh terhadap mortalitas pasien neonatus pascaoperasi adalah usia gestasi $<37$ minggu/pematur, dan PCA <60 minggu, neonatus berat badan $<2.500$ gram, ASA III atau lebih, faktor penyulit preoperatif $\geq 2$, serta lama operasi lebih dari 2 jam.

\section{Daftar Pustaka}

1. Morgan GE. Pediatric anestesi. Dalam: Morgan GE, Mikhail MS, Muray MJ, penyunting. Clinical anesthesiology. Edisi ke-5. New York: McGraw Hill; 2012. hlm. 877-905.

2. Silva JM, Ribas AM, Oliveira RD, Nogueira FA, Vianna FM , Filho MC. The effect of excess fluid balance on the mortality rate of surgical patients: a multicenter prospective study. Crit Care. 2013;17(R288):1-7.

3. Stewart R, Walsh, Tjun Y, Coveney. Perioperative fluid restriction reduces complications after major gastroentistinal surgery. Spec Reg Gen Surg. 2008;143(4):466-8.

4. Ketharanatha N, McCulloch M, Wilson C, Rossouw N, Salie S, Ahrens J. Fluid overload in a South African Pediatric Intensive Care Unit. Erasmus University Rotterdam Oktober 2014. J Trop Pediatr. 2014;60(6):428-33.

5. Lowell JA, Schifferdecker C, Driscoll DF, Benotti PN, Bistrian BR. Postoperative fluid overload: not a benign problem. Crit Care Med. 1990;18(27):728-33.

6. Sutherland SM, Zappiteli M. Fluid overload and mortality in children receiving continuos renal replacement therapy: the prospective pediatric receiving continuos renal replacement therapy. Am J Kidney Dis. 2010:55(3):316-25.
7. Lieharrt A, Auoroy Y, Bovet M, Survey of anesthesia related mortality in France. Anesthesiology. 2006;105:1087-97.

8. Machanda V, Sarin YK, Ramji S. Prognosis factors determining mortality in surgical neonatus. J Neon Surg. 2012;1(1):1-7.

9. Ilori IU, Ituen AM, Eyo CS. Factors associated with mortality in neonatal surgical emergencies in a developing tertiary hospital in Nigeria. Open J Pediatr. 2013;3:231-5.

10. Gangopadhyay AN, Upadhyaya VD, Sharma SP. Neonatal surgery: a ten year audit from a University Hospital. Ind J Pediatr. 2008;75(10):1025-30.

11. Farroow SC, Fowkes FG, Lunn JN, Samuel P. Epidemiology in anaesthesia II: factors mortality in hospital. $\mathrm{Br} \mathrm{J}$ Anaesth. 1982;52:811-7

12. Kuremu RT, Kituyi PW, Tenge CN, Kerubo. Neonatal surgical emergencies at Moi Teaching and referral hospital in Eldoret-Kenya. East Centr African J Surg. 2007;12(2):36-9.

13. Catre D, Lopes MF, Matrigal A, Oliveiros B, Viana JS, Cabrita AS. Early mortality after neonatal surgery: analysis of risk factor in an optimized health care system for the surgery newborn. Rev Bras Epidemiol. 2013;16(4):943-52.

14. Ayse A, Zappitelli M, Stuart L, Naipaul A, Larry S, Loftis L. Fluid overload is associated with impaired oxygenation and morbidity in critically ill children. Pediatr Crit Care Med. 2012;13(3):233-8.

15. Rocca GD, Vetrugno L, Tripi G, Deana C, BarbariolF, Pompei L. Liberalor restricted fluid administration: are we ready for a proposal of a restricted intraoperative approach?. BMC Anesthesiol. 2014;14:1-8.

16. Lee J, Louw ED, Niemi M, Nelson R, Mark RG, Leo A, dkk. Association between fluid balance and survival in critically ill patients. J Intern Med. 2015;277(4):46877.

17. Lobo DN, Macafee DA, Allison SP. How perioperatif fluid balance influences postoperative output. Best Pract Resc Clin Anest. 2006;20:439-55. 